\section{RISK FACTORS OF HYPERTENSION AMONG ADULTS IN A SEMI URBAN COMMUNITY IN SOUTH WEST NIGERIA}

Osalusi, Bamidele Sanya*; Ogunjimi, Lukman; Uantioje Ikhifa, Ale, Ayotunde; Ogunsemi, Olawale Afe T.O; Adeleye, Olufunke

Department of Medicine, Obafemi Awolowo College of Medicine,Olabisi Onabanjo University Corresponding Author; Email - sanyabamidele@yahoo.com

\section{ABSTRACT}

Recent studies have shown an increasing trend in the prevalence of hypertension in rural communities. This study aimed to investigate the prevalence of risks factors for hypertension among the residents of Likosi town, Sagamu local government area, Ogun state, Nigeria. A descriptive crossdefined as Systolic blood pressure (SBP) 140 and/or Diastolic blood pressure (DBP) 90 . statistical analysis was performed using the SPSS package.

The prevalence of hypertension was $23.3 \%$ (male $11.2 \%$ and female $12.1 \%$ ). The mean age of the respondents was 37.5years. Mean systolic and diastolic BP were $124.25 \pm 15.05 \mathrm{mmHg}$ and 83.45 $9.49 \mathrm{mmHg}$, respectively. Higher odds of being hypertensive were found in 31-40 age group, The prevalence of the various classes of body mass index of the respondents were $18.5 \%, 45.1 \%, 15.1 \%$ and $24.3 \%$ for underweight, normal, overweight and obese respectively. Alcohol and tobacco use were found in $34.5 \%$ and $15.4 \%$ respectively. Hypertension was significantly associated with age groups $30-49$ years (OR 2.258, $95 \%$.

Keywords: hypertension, prevalence, risk factors, body mass index

Accepted Date: 27 May 2020

\section{INTRODUCTION}

Hypertension, a major public health problem challenge worldwide usually occurred as a result of environmental influences acting over time on the genetically predisposed individual (George 1967 ,Lopez et al 2003). It has become a significant problem in many developing countries, with majority of them experiencing epidemiological transition from communicable to non communicable chronic diseases. The emergence of hypertension as a public health problem in these countries is strongly related to the aging of the populations, urbanization and socioeconomic changes that favors sedentary habits, obesity, alcohol consumption, and salt intake amen, alcohol consurion, ers(Lopez et al 2003)

Risk factors such as smoking, obesity or being overweight, diabetes, sedentary lifestyle, lack of

physical activity, high levels of salt intake (sodium sensitivity), insufficient calcium, potassium, an magnesium consumption, vitamin D deficiency, high levels of alcohol consumption, stress, aging, igh leves of alcohing, aging, medicines such as birth control pills, genetics and family history of hypertension, chronic kidney disease, adrenal and thyroid problems or tumour have been highly associated with the condition (Mabuza 2009). Hypertension often coexists with other cardiovascular risk factors, such as diabetes, hyperlipidemia and obesity, which compound the cardiovascular risk attributable to hypertension. Often times, these coexistent risk factors are inadequately addressed in patients with hypertension, resulting in high morbidity and thpent mortality (Klungel et al. 199). It has become me of the risk factors of stroke, ischemic heart disease and renal failure are not confined to a subset of the population with particularly high levels of blood pressure, but rather, it is a risk factor even in a continuum moderate level of blood pressure (MacMahon et al 1990).

In 2001, chronic diseases contributed approximately $60 \%$ of the 56.5 million total reported deaths in the world and approximately $46 \%$ of the global burden of disease (World Health the burden of non-communicable diseases is expected to increase to $57 \%$ by 2020 (World Health Organization 1998). Hypertension is also recognized as a silent killer due to the damages it causes on the target organs on a continuous and progressive basis until symptoms are manifested (Macmillan et al 1990). It increases the chance of an individual's risk of having various cardiovascular diseases by two to three times with devastating consequences (Padwal et al 2001).

Recently, the prevalence of predisposing factors to hypertension, is rising in developing countries and the burden is worse in persons with lower socioeconomic status (World Health Organisation, 2002). Hypertension is becoming an increasingly common health problem worldwide because of increasing longevity and prevalence of contributing factors (Yusuf et al.2000). The current prevalence in many developing countries hose seen in deve 2002). . with high blood pressure, so many people with high blood pressure are unaware they have it (Russell et al 1991). In Nigeria, awareness is poor as only $33.8 \%$ of hypertensive are aware of their condition (Familoni at al 2002, Akinkugbe et al 2003, Kadiri et al. 2005). Moreover, the more worrisome situation is the trend of poor blood pressure control worldwide. A study revealed that slightly more than half of adults with hypertension were aware of heir disease, fewer the their disease, fewer than half were treated for their hypertension with medications; and less than twothirds were controlled to $<140 / 90 \mathrm{mmHg}$ with medication (Marques-Vidal \& Toumilehto 1997). Futhermore, a situation that has been called "the rule of halves" is becoming rampant. In most communities, only about $50 \%$ of those who are hypertensive are aware of their condition and less than $50 \%$ of those who are aware are receiving adequate treatment (Marques-Vidal \& Toumilehto
1997)

In Nigeria, the prevalence of high blood pressure was between ten and fourteen percent based on national survey conducted over a decade ago (Familoni et al 2002, Akinkugbe et al 2003). Since that survey, social and demographic changes have taken place which may influence changes in the prevalence and epidemiology (Kadiri et al 2005) A recent community based study of rural and semi(igemi(E) 2015), 2015 ), while a meta analytical study published recently estimated the country wide prevalence to be between $12.4 \%$ and $34.8 \%$, this means that 20 to 56 million Nigerians are hypertensive (Kadiri et al. 2005). The aims of the study is therefore, to determine the prevalence of Hypertension and its associated risk factors in the semi urban community, in order to reduce the risk of morbidity and mortality.

\section{Methodology}

Description of the Study Area

The study was carried out in Likosi town of Ogijo community under the Sagamu Local Government Area of Ogun State. Likosi community is in the North East Area of Sagamu with a geographical coordinate of 642 ' 0 " North, 3 31'0" East. has a population of about two hundred and fifty thousand. The study population consisted of adults (males and females) in Likosi area of Ogijo between the ages of twenty (20) and eighty (80) years.

Eligibility Criteria: Inclusion and exclusion criteria

Adults in Likosi community between the ages of twenty (20) and eighty ( 80 ) years who were willing to participate in the study were recruited into the study. Those who were less than 20 years as at last birthday were excluded from the study.

\section{Study Design}

The study was a cross sectional descriptive survey aimed at determining the prevalence of hypertension risk factors among adults in Likosi Community of Sagamu Local Government area, Ogun State. 
Sample Size Determination

The sample size was determined using the formula: $\mathrm{n}=\mathrm{z} 2 \mathrm{p} \cdot \mathrm{q}$

d2 Where,

$\mathrm{n}=\quad$ desired sample size

$\mathrm{z}=$ the standard normal deviate set at 1.96 confidence interval

$\mathrm{p}=$ proportion estimated to be obtainable in target population $(34.8 \%)$

$q=$ proportion that does not have the characteristic being investigated i.e. $q=1-p$ $\mathrm{d}=$ degree of accuracy required $=0.05$

Therefore,

Approximately 350

\section{Sampling Methodology}

Amulti-stage random sampling technique was used for the selection of respondents for the questionnaire.

Stage I: The selection of Likosi community was done by random sampling method.

Stage II: Fourteen streets were randomly selected and 25 respondents were randomly selected in each of the selected streets.

Stage III: A total of three hundred and fifty (350) respondents were given questionnaires and their blood pressure measured.

Participants were recruited from the market / work place(s) and from their residences.

\section{Data Collection Instruments}

An interviewer administered questionnaire method was used. The questionnaire was developed after a review of the literature. It was pretested in Simawa community in Mowe Local Government Area. The blood pressure was taken using Aneroid sphygmomanometer on the right arm after 10minute rest in a sitting position. The first and fifth hases of Korokleff sounds were taken as systolic phases of Korotkoff sounds were taken as systolic and diastolic blood pressure, respectively. Average two readings were recorded as the subject blood pressure. Blood pressure measurements were done by the interviewer. Measurements were done between the hours of 9 am and $11 \mathrm{am}$. The body mass index was determine using standard method. Weight and height were measured using a standard weighing scale and Seca stadiometer respectively. The pre-test was conducted on a sample size of 50 respondents. The Body mass index (BMI) was calculated as weight / (height $)^{2}$. Joint National Committee on Prevention, Detection, Evaluation and Treatment of High Blood Pressure (JNC 7) classification was used for hypertension (Chobanian et al 2003). Hypertension was defined as systolic BP level of $\geq 140 \mathrm{mmHg}$ and/or diastolic BP level of $\geq 90 \mathrm{mmHgl}$.Hypertension was defined as Systolic blood pressure (SBP) $\geq 140$ and/or Diastolic blood pressure (DBP) $\geq 90 \mathrm{~mm} \mathrm{Hg}$.

\section{Data Collection Techniques Procedures}

The survey was conducted among adults between the ages of twenty (20) and eighty (80) years old in the Likosi area of Ogijo community. The study was introduced to the respondents and they were info rmed that questionnaires will be filled following which their blood pressure, weight and height will be measured. They were assured of confidentiality. Respondents were selected at random from the market, offices and from places of residence.

The method/instrument used in collecting data was questionnaire (privately filled face to face questionnaire). Face to face interview is preferred to self-administration of questionnaire because field experiences in Nigeria show that the forme usually yield better rates of responses and produce good quality data than the latter (Ulasi II et al 2010).

\section{Data Analysis}

The data collected were collated and statistical analysis was performed using the SPSS 16

Results

A total of 350 subjects participated in the study. Out of these, 193 (55.1\%) were male subjects and $157(44.9 \%)$ were female. The highest proportion of the respondents $(136,38.9 \%)$ were found in the age range 31-40yrs. The median age (37.5 $11.6 \mathrm{SD}$ ) of the study subjects was $37.0( \pm 11.9)$ years and for male and female it was $36.0( \pm 11.9)$ years and 38 $( \pm 11.8)$ years, respectively. Major ( 11.8$)$ years, respectively. Majorty of the participats $253,72.3 \%$ (2.5\%) while $7(22.5 \%)$ and $9(2.5 \%)$ had secondary an tertiary education respectively. Majority of the participants were married $(215,61.4 \%)$ while 98 $(28 \%)$ and $37(10.6)$ were divorced (TABLE 1)
Table 1: Characteristics of respondents

\section{Biodata \\ Frequency $(\mathbf{n}=\mathbf{3 5 0})$}

\section{Percentage (\%)}

\section{Age in years}

$\begin{array}{lll}20-30 & 81 & 23.1 \\ 31-40 & 136 & 38.9 \\ 41-50 & 75 & 21.4 \\ 51-60 & 40 & 11.4 \\ 61-70 & 15 & 4.3 \\ 71-80 & 3 & 0.9\end{array}$

Gender

Males

Females

\section{Educational Level}

None

Primary

Secondary

Tertiary

\section{Religion}

Christianity

176

Islam

Religion

Marital Status

Single

Married

215

Seperated

37

The prevalence of hypertension was found to be $23.7 \%$. Mean $( \pm \mathrm{SD}) \mathrm{BMI}$ of the study subjects was $24.8 \pm 3.82 \mathrm{~kg} / \mathrm{m} 2$; for men it was $23.72 \pm 3.81$ $\mathrm{kg} / \mathrm{m} 2$ and for women it was $24.42 \pm 3.92 \mathrm{~kg} / \mathrm{m} 2$. The $\mathrm{kg} / \mathrm{m} 2$ and for women it was $24.42 \pm 3.92 \mathrm{~kg} / \mathrm{m} 2$. The
prevalence of BMI $(\mathrm{kg} / \mathrm{m} \mathrm{2})$ of the respondents prevalence of BMI $(\mathrm{kg} / \mathrm{m}$ 2) of the respondents
$18.3 \%, 45.1 \%, 15.1 \%$, and $21.4 \%$, were. $18.3 \%, 45.1 \%, 15.1 \%$, and $21.4 \%$, were.
underweight, normal, overweight, and obese underweight, normal, overweight, and obese he respondents were either underweight or normal while $36.5 \%$ were either overweight or obese.

$15.4 \%$ of respondents engage in drinking of alcohol $\{>21$ unit of alcohol per week for male and 14 unit of alchol for female), cigarette smoking $34.6 \%$, (at least pack of cigarrette per day) as well $34.6 \%$, (at least pack of
as inactivity in $55.1 \%$.
23.1

1.4

1.3

9

Table 2 depicts blood pressure profile according to the different age groups. The mean values of systolic and diastolic BP according to age table 3. The mean systolic and diastolic BP of all the study subjects were $126.2 \pm 15.0 \mathrm{mmHg}$ and $85.2 \pm 10 \mathrm{mmHg}$, respectively. The highest mean systolic BP and mean diastolic BP were among the 51-60 age group and age group (41-50 years), respectively. With regard to systolic BP, there was significant difference among all the age groups among and the same was with diastolic BP as well. 
Table 2: Blood Pressure Profile Within Age Groups

\begin{tabular}{lcc}
\hline Age groups & $\begin{array}{c}\text { Frequency and Percentage } \\
\text { Normal } \\
\text { High }\end{array}$ & $9(2.6 \%)$ \\
$20-30$ years & $72(20.6 \%)$ & $30(8.6 \%)$ \\
$31-40$ years & $106(30.3 \%)$ & $18(5.1 \%)$ \\
$41-50$ years & $57(16.3 \%)$ & $17(4.9 \%)$ \\
$51-60$ years & $23(6.6 \%)$ & $9(2.6 \%)$ \\
$61-70$ years & $6(1.7 \%)$ & - \\
$71-80$ years & $3(0.9 \%)$ & $\mathbf{8 3}(\mathbf{2 3 . 7 \% )})$ \\
Total & $\mathbf{2 6 7 ( 7 6 . 3 \% )}$ &
\end{tabular}

\section{Ç! • [ 9 जMEAN SYSTOLIC AND DIASTOLIC BP BY AGE}

\begin{tabular}{|c|c|c|}
\hline ! D9 Dwh Üt & \{ò $\{C ̧ h[L$ & $5 \mathrm{~L}\}\{C ̧ h[\mathrm{~L}$ \\
\hline 30 30-وو & لِّلآيوفىوو & و \\
\hline 40-وى & لآ هوصىوو & 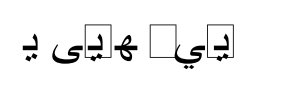 \\
\hline 50-وى & ووو بوكىىو & 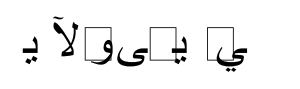 \\
\hline 60-وي & 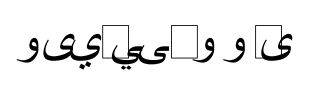 & يـا وووسى هـ بـ \\
\hline 70-وي & 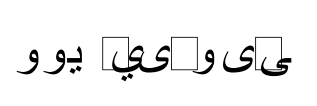 & يَلآهـي يـي \\
\hline 80-و يـ & كى وووطيوو & لَّ \\
\hline
\end{tabular}

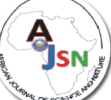

The prevalence of isolated systolic $\mathrm{BP}$ was found to be $3.4 .6 \%$ and isolated diastolic BP was $19.7 \%$. figure1. However the age range of $31-40$ years had the highest hypertensive. While the prevalence rate of hypertension for this study was found to be $23.7 \%$. Table 4 shows the associated factors of hypertension, education status, alocohol use, tobacco use, and physical activity were significantly associated with the hypertension status of the study subjects.

\section{FIG 1; ISOLATED SYSTOLIC AND DIASTOLIC BP BY AGE AND GENDER}

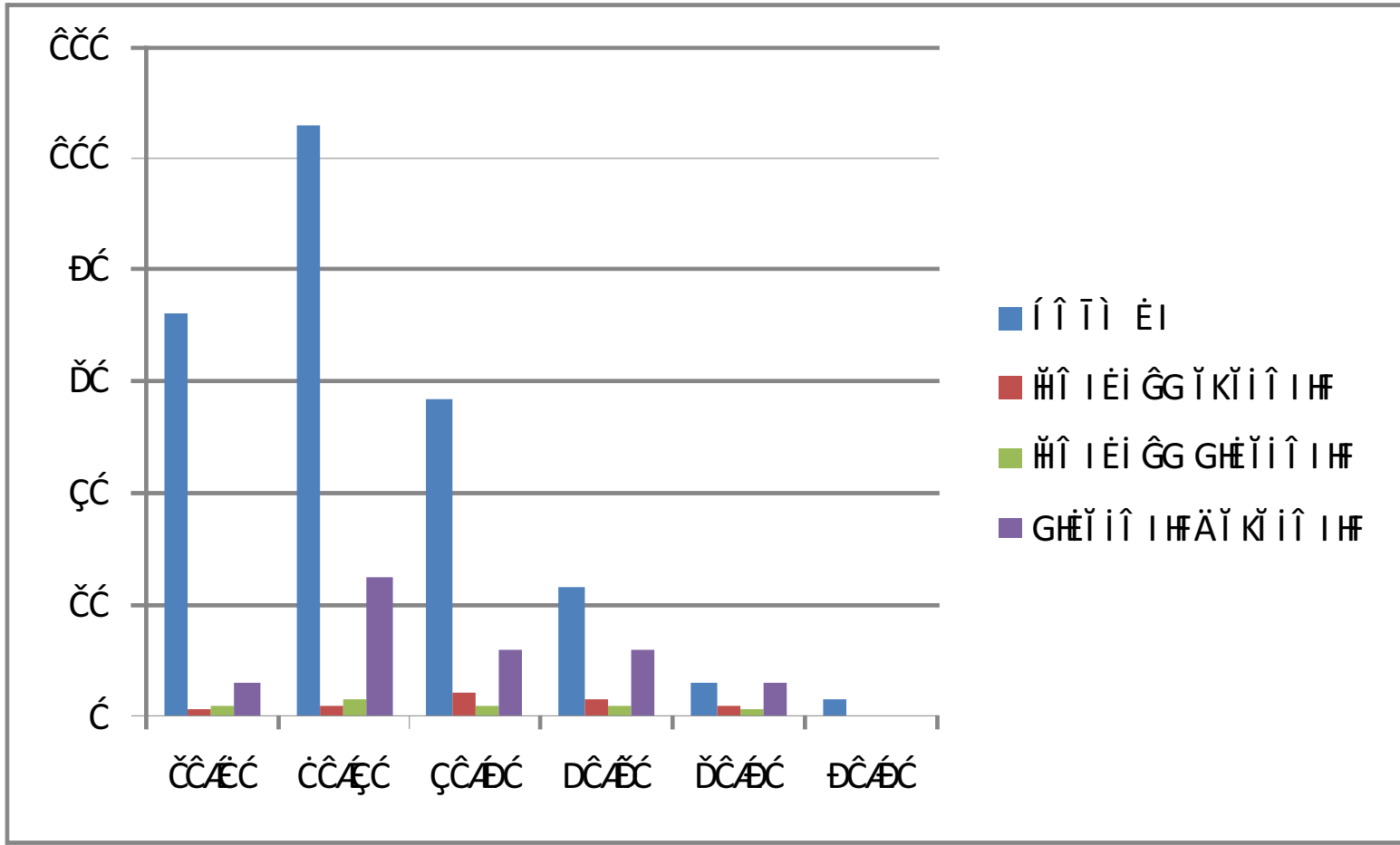


Table 4: Prevalence of hypertension according to behavioral risk factors and sociodemographic characteristics

\begin{tabular}{|c|c|c|c|}
\hline VARIABLES & HYPERTENSIVES & NONHYPERTENSIVE\% & $\begin{array}{l}\text { TEST OF } \\
\text { SIGNIFICANCE } \\
\text { USING X }{ }^{2}, P \\
\text { VALUE h̆ É ḰD Å }\end{array}$ \\
\hline LEVEL OF & & & 0.037138 \\
\hline $\begin{array}{l}\text { EDUCATION } \\
\text { NONE }\end{array}$ & 3 & 6 & \\
\hline PRIMARY & 4 & 5 & \\
\hline SECONDARY & 26 & 53 & \\
\hline TERTIARY & 50 & 203 & \\
\hline TOTAL & 83 & 267 & \\
\hline $\begin{array}{l}\text { FAMILY } \\
\text { HISTORY OF }\end{array}$ & & & $<.00001$ \\
\hline HYPERTENSION & & & \\
\hline $\begin{array}{l}\text { POSITIVE } \\
\text { FAMILY } \\
\text { HISTORY }\end{array}$ & 31 & 186 & \\
\hline $\begin{array}{l}\text { HISTORY } \\
\text { NEGATIVE }\end{array}$ & 52 & 81 & \\
\hline $\begin{array}{l}\text { FAMILY } \\
\text { HISTORY }\end{array}$ & & & \\
\hline TOTAL & 83 & 267 & \\
\hline $\begin{array}{l}\text { BODY MASS } \\
\text { INDEX }\end{array}$ & & & $<0.00001$ \\
\hline$<25.0$ & 4 & 60 & \\
\hline $25.0-29.9$ & 18 & 140 & \\
\hline $30.0-34.9$ & 21 & 32 & \\
\hline$>35$ & 40 & 35 & \\
\hline SEX & & & 0.378293 \\
\hline MALE & 40 & 114 & \\
\hline FEMALE & 43 & 153 & \\
\hline $\begin{array}{l}\text { PHYSICAL } \\
\text { ACTIVITY }\end{array}$ & & & \\
\hline MEET WHO & & & 0.001997 \\
\hline $\begin{array}{l}\text { PHYSICAL } \\
\text { ACTIVITY }\end{array}$ & & & \\
\hline $\mathrm{NO}$ & 58 & 135 & \\
\hline YES & 25 & 132 & \\
\hline TOBACCO USE & & & $<0.00001$ \\
\hline NEVER & 23 & 188 & \\
\hline STOPPED & 26 & 59 & \\
\hline STILL SMOKING & 34 & 20 & \\
\hline
\end{tabular}

ALCOHOL USE

0.000241
! [ / h I h [ Ü $\{9$

0.000241

\begin{tabular}{|c|c|}
\hline $\begin{array}{l}\text { b } 9 \ddot{e} 9 w \\
\{\text { Chtt } 95\end{array}$ & ئوي \\
\hline \{ÇL [ $5 \mathrm{wlb}$ Y Ib D & لآثى \\
\hline
\end{tabular}

Figure 2. ASSOCIATION BETWEEN ALCOHOL USE AND BLOOD PRESSURE

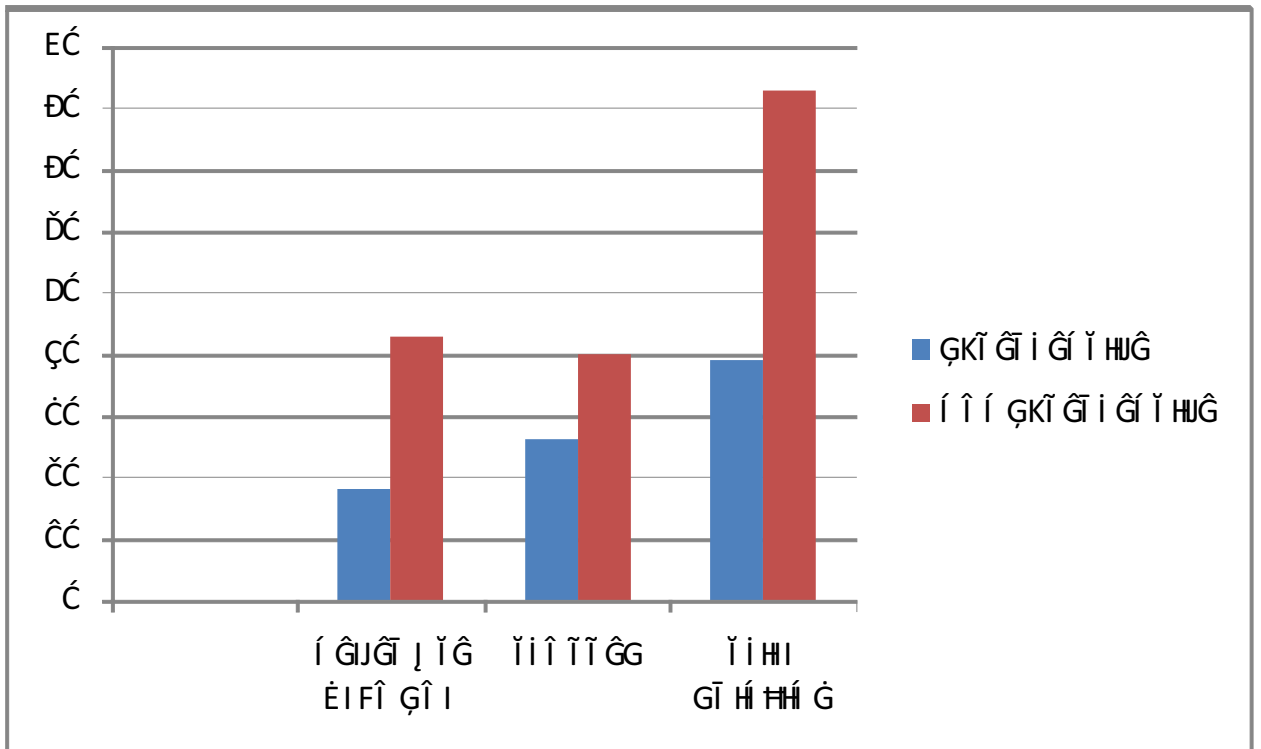

Figure 3 ASSOCIATION BETWEEN TOBACCO USE AND BLOOD PRESSURE

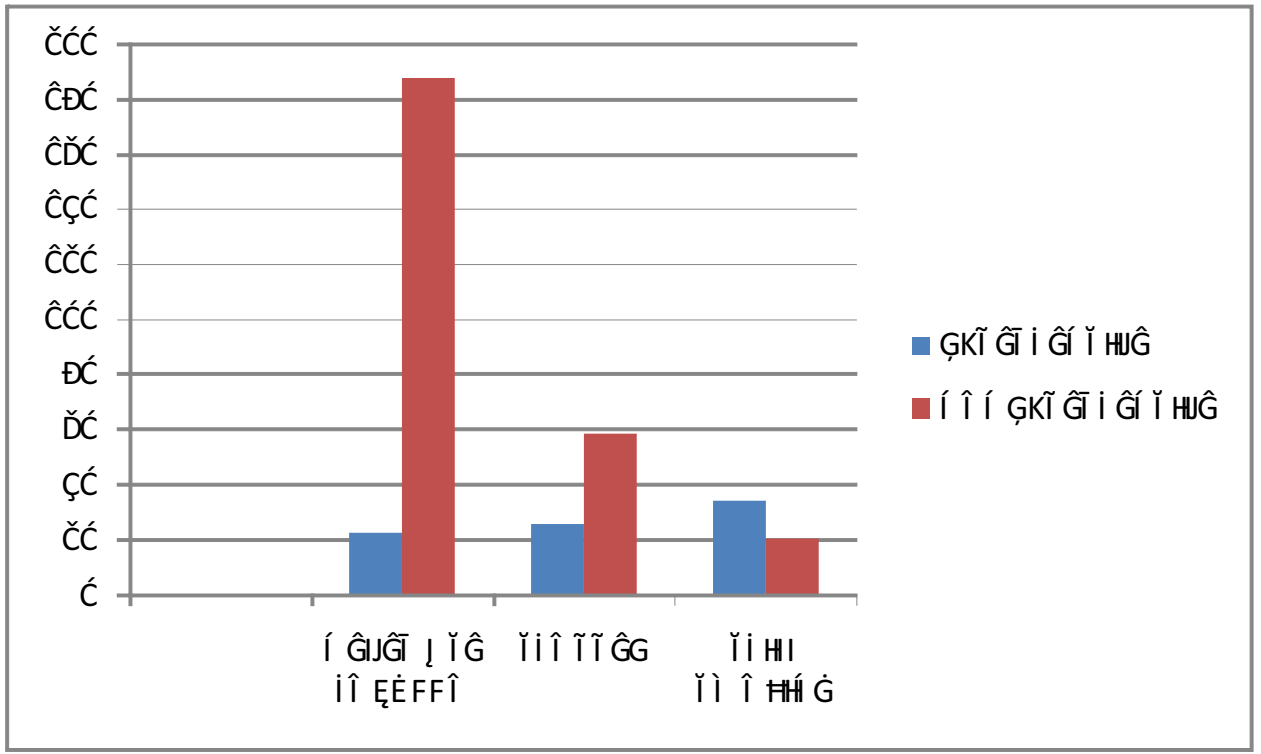

Hypertension was higher among 31-40years age group $(8.6 \%)$, among respondents with tertiary education compare to those with no education (RR; 0.59 , OR: 0.49). With regard to anthropometric risk factors, being overweight (RR:1.82, OR:1.93), being obese (RR: 6.34 , OR;9.84), and having morbid obesity (RR;8.53,

OR;17.14) had higher odds of hypertension compared to normal BMI. Tobacco use (OR $6.2080,95 \%$ CI), alcohol use (OR: $3.1788,95 \%$ CI), had higher odds of being hypertensive. Age, BMI, and tobacco and alocohol use were significantly associated with hypertension. 
were associated with hypertension (table 4) staying away from any kind of addiction could serve as protective factors against hypertension.

\section{Discussion}

The total number of respondents in this study was 350. The age range with the highest percentage of respondents was between ages $31-40$ years $(38.9 \%)$ This was similar to $38.02 \pm 13.3$ years found in surey of hypertion and its awareness amongst traders and artisans in Ogbete Market, Enugu State (Ulasi et al., 2011). There were more male respondents, $193(55.1 \%)$ as against $157(44.9 \%)$ female respondents. This was similar to the survey in China and the USA where more men were involved (Xia Li, et al. 2013, Wyatt et al. 2008). This disagrees with the sex distribution of respondents in a survey of hypertension among residents of Ajegunle community, a popular slum in Lagos Ste Nite $34.2 \%$ (n). The (female) (Daniel et al. 2013 statistical significant risk of having hypertension between the male and female gender. This was not consistent with previous studies where men were found to be at a greater risk of being hypertensive (Klungel et al. 1999, Kadiri et al. 2005 \& Daniel et al. 2013).. However a study by Adediran et al. did not also find any statistically significant gender difference in tendency of being hypertensive in their study of hypertension prevalence in an urban and rural area of Nigeria. In our study, more females $(12.1 \%)$ had hypertension compared to males (11.2\%). This was different from the findings in several community-based studies: Survey of hypertension among residents of a rural community in South-East Nigeria, where it was $(50.2 \%)$ male and $(44.8 \%)$ female [22]. However a survey of hypertension in a rural community in Eastern Nigeria: Male (49.3\%), female (42.3\%) [24]; in a survey of hypertension amongst herdsmen living in Tibet, China: Male $(66.1 \%)$ female $(48.3 \%)$ in 25$]$. Our finding Was simile hypertience of hypertension was higher among females (79.6\%) compared to males $(74.4 \%)$ in a survey of
hypertension in an older adult population in South Africa (Peltzer et al 2013).

Normal BP were recorded in 267 (76.3\%). The overall prevalence of hypertension in this study was $23.7 \%$, this was lower than what was found in 95 geographical clusters in Mozambique (Damasceno et al 2009) as well as $32.8 \%$ found in three communities in Enugu North LGA of Enugu State, Nigeria (Ulasi et al 2010). The overall of prevalence of hypertension in this study was highe than $18.3 \%$ found in Kegbara-Dere; a rura community in the Niger-Delta Region of Nigeria (Onwuchekwa et al 2012) and . 9.3\% found among urban workers in Ibadan city (Olatunbosun et al. 2000 ) as well as $10.3 \%$ found in a civil service population in Ibadan city (Olatunbosun et at. 2000). However popur. among the inhabitants of three rural communities in Akwa-lbom and Cross-River (States) Andy et al. 2012). This wide margin further confirmed the upsurge of hypertension in communities across Nigeria. The overall prevalence of $23.7 \%$ was however lower than $36.6 \%$ found among adult residents of Ile-Ife in Osun State, Nigeria (Adedoyin et al. 2008) and 38.2\% found among (Adult residents of Ajegunle in Lagos State, both in the same southwestem part of Nigeria (Daniel at 2013). However prevalence of hypertel al. 2013). However, prevalence of hypertension in pre estimate prevalence of hypertension for WHO African
Region(World Health Organization 2013). In our study, the age range of 31- 40 years had the highest of hypertensive. prevalence of hypertension increased with age. This was differen from findings in most recent community-based studies conducted in Nigeria (Ahaneku et al. 201 Ulasi et al 2010; Onwuchekwa et al 2012), where Age was the only sociodemographic factor that was significantly associated with hypertension. Our finding was different from the result of a survey of hypertension among adult residents of Ajegunle community, Lagos State, Nigeria (Daniel et al. 2013) a survey of hypertension among adults patients attending a Missionary Hospital in Ibadan, Oyo State, Nigeria (Ajayi et al 2016) and in a survey of $\mathrm{BP}$ gradients and cardiovascular risk factors in urban and rural populations in Abia State Nigeria (Ajayi et al 2016). However our finding was (Ajari et al 2016). However our finding was sing in a rura community in Eastern Nigeria (Ahaneku et al.

Using the BMI $(\mathrm{kg} / \mathrm{m}$ 2) of the respondents $18.3 \%$ $45.1 \%, 15.1 \%$, and $21.4 \%$, were.underweight normal, overweight, and obese respectively. More than half $(63.4 \%)$ of the respondents were either underweight or normal while $36.5 \%$ were either overweight or obese. Numerous studies had established the association between BMI and hypertension (Daniel OJ et al. 2013, Ogah OS et al 2013, Ogunniyi A et al 2001). BMI is one of the most accurate ways to determine when extra body weight translates into health risks (Erhun WO et al. 2005).. BMI as a risk factor was significantly associated with hypertension. In our study out of 75 Obese respondents $40(53.3 \%)$ had hypertension. This agreed with the findings in a survey of hypertension among adult patients attending a Missionary Hospital in Ibadan, Nigeria (Ajayi IO et al 2016), survey of hypertension among herdsmen living in Tibet, China (Zhao X et al 2012). In a survey of hypertension among residents of Ajegunle, Lagos State, Nigeria (Daniel OJ et al. 2013). Thus being overweight or obese was a predictor of hypertension. Compared to those with BMI in the normal category, the odds of developing hypertension was 2 times more among those in the overweight/obese category.

The overall prevalence of family history of hypertension in the population was $38.9 \%$ ( $=350$ ), irrespective of blood pressure status. A family history of hypertension was present in $37.35 \%(\mathrm{n}=83)$ of subjects with hypertension. Presence of a family history increased the risk of hypertension (OR: 0.2596; 95 \% CI: $\mathrm{p}<0.0001$ ) this was similar to other studies. In this study the prevalence of hypertension was the lowest $3,6 \%$, in subjects with no formal education and the highest, $69.9 \%$ in those with tertiary education, this is different from findings in previous studies but similar to that of cross country studies where educated health workers (nurses) were found to have highest prevalence (David et al 2015).

The prevalence of alcohol consumption in the study was $34.6 \%$ This was lower than $43.4 \%$ found in Delta State (Ajayi IO et al 2016). The prevalence of alcohol consumption in Ogijo community was very high; this can be attributable to the fact that in the community alcoholic beverages is a common feature of many social gatherings, also among oil workers and those working in the industries. Heavy alcohol consumption, on the other hand carries adverse health and social consequences due to its intoxicating and addictive properties (Ajayi IO et al 2016). Alcohol consumption showed significant association with hypertension prevalence in our study this was similar to another study where consumption showed significant association with hypertension. There were inconclusive evidences of the effect of alcohol on hypertension in most studies in Africa; some show association of regula and moderate alcohol intake and others show no association. The prevalence of cigarette smoking in the study was $15.4 \%$. This is similar to that found in a rural community in Delta State where the prevalence was $15.8 \%$ (Ajayi IO et al 2016), and Edo State where the prevalence was $16.8 \%$ (Onwubere et al 2011, Onwuchekwa AC et al 2012) as well as that found among U.S adult citizens in 2011, where the prevalen a was citizens in 2011 , where the CJ 1997). It is was recorded as 19.0\% (Murray CJ 1997). It is not surprising that the prevalence of smoking from studies in Nigeria are close to that of the United States. This can be attributed to modernization and westernization of our culture, where the western culture and style of living are copied and emulated regardless of its negative effect on health. Several studies have acknowledged smoking especially cigarette smoking as one of the major causes of non-communicable and chronic disease (Murray CJ 1997 Kearney PM. 2005). Although it has been reported that regular and long time cigarette smoking is associated with higher blood pressure, this study showed statistically significant difference between smokers and nonsmokers on the risk of developing hypertension. Hypertension was diagnosed more frequently in sedentary subjects (those who did not meet WHO physical activity standards) $58(69.76 \%)$ than in physically active subjects $25(30.12 \%)$ this finding statistically significant (OR; O,4408, 95\% $P=0.0023$. This $\mathrm{P}=0.0023$. This sudy was limited in that it was based on self-reporting of physical activity where the trend to overreport the actual level of physical activity is well known. Physical activity can be assessed subjectively using self-reported questionnaire or objectively (directly measured) using equipment such as pedometers or accelerometers. Self-reported questionnaires are commonly used in primary care centre because they are cheap and easy to use. However, both methods have drawbacks and are subjected to potential bias. Self-reported questionnaires may not be able to capture all types of physical activity, whereas certain devices may not be worn in activities such as swimming to measure physical activity. Previous literature recommended using both objective and subjective measurements to validate the results for better measurements and physical activity recording (Onwubere et al 2011 David Guwatudde. et al 2015). 


\section{Conclusions}

A high prevalence of hypertension was recorded in this study. About one-third of the respondents were hypertensive. This finding has public health implication as it puts one in every three adults in the community at-risk of cardiovascular disease (s). It was also found that majority of the hypertensives were not aware of their status prior to the survey. This underscores the need for urgent steps to create This uness and implement interventions for wareness and inplement interventions for prevention and early detection of hypertension
especially among those aged $\geq 30$ years and the overweigh, /obese and morbidly obese individuals. Hypertension was significantly associated with age groups 30-49 years.. Tobacco and alcohol consumption, overweight, obesity, and abdominal obesity were also associated with hypertension

\section{Study limitation}

The major limitation of this study was the sole reliance on the respondents' reports and the assumption that the questions were well understood by the respondents

\section{References}

Akinkugbe OO (2003). Current epidemiology of hypertension in Nigeria. Archives of Ibadan Medicine. 1:3-5.

Adediran Olufemi Sola, Okpara Ihunanya Chinyere, Adeniyi Olasupo Stephen (2013). Hypertension prevalence in an Urban and Rural area of Nigeria. Journal of Medicine and Medical Sciences. 4 (4): 149154.

Andy JJ, Peters EJ, Ekrikpo UE (2012). Prevalence and correlates of hypertension among the Ibibio/Annangs, Efiks and Obolos: A cross sectional community survey in rural SouthSouth Nigeria. Ethn Dis. 22:335-9.

Adedoyin RA, Mbada CE, Balogun MO et al (2008). Prevalence and pattern of hypertension in a semiurban community in Nigeria. Eur J Cardiovasc Prev Rehabil. 15,683-7.

Ajayi IO, Sowemimo IO, Akpa OM (2016). Prevalence of hypertension and associated factors among residents of Ibadan-North Local Government Area of Nigeria. Nig J Cardiol. 13:67-75.
Ahaneku GI, Osuji CU, Anisiuba BC(2011). Evaluation of blood Pressure and indices of obesity in a rural community in Easter Nigeria. Ann Afr Med. 10, 120-6,

Chobanian AV, Bakris G L., Black H R. et al (2003)., "Seventh report of the Joint National Committee on prevention, detection, evaluation and treatment of high blood pressure," Hypertension, 42(6):2 1206-1252.

Daniel OJ, Adejumo OA, Adejumo EN(2013). Prevalence of hypertension among urban slum dwellers in Lagos, Nigeria. J Urban Health. 90, 1016-1025

Damasceno A, Azevedo A, Silva-Matos C, (2009). Hypertension prevalence, awareness, treatment, and control in Mozambique: Urban/rural gap during epidemiological transition. Hypertension. 54:77-83

David Guwatudde. et al (2015). BMC Public Health; The burden of hypertension in sub-
Saharan Africa: a four-country cross Saharan Africa: a four-countr
sectional study. 1211: 12889-015

Erhun WO, Olayiwola G, Agbani EO, (2005) Prevalence of hypertension in a university community in South West Nigeria. Afr Biomed Res CIbadan Biomedical Communications Group. Available from. 8:15-9.

Effiong Ekong Akpan, Udeme E, Ekrikpo, Aniema IA(2015). Prevalence of Hypertension in Akwa Ibom State, South-South Nigeria: Rural versus Urban Communities Study International Journal of Hypertension, International Jo

Familoni OB (2002). Hypertension - how much do our patients know? African Health. 24(3) 13.

George Pickering (1967). The Nature of Essential Hypertension, New York: Grune and Straton, 10-21.

Kearney PM, Whelton M, Reynolds K (2005). Global burden of hypertension: analysis of worldwide data; Lancet. 365,217-230

Klungel OH, Diane BM, Anthonius DB et al (1999). Recruitment of participant through community pharmacies for a pharmacogenetic study of antihypertensive drug treatment. Pharmacy World \& Science. 30: 1312-1318.
Kadiri S (2005). Tackling cardiovascular diseases in Africa. BMJ West African Edition. 8(4): $172-173$

Marques-Vidal P, Toumilehto J(1997). Hypertension awareness, treatment, and control in thecommunity. Is the rule of halves still valid? J. Hum. Hypertension. 1(1) 213-220.

Lopez, Mathers, Ezzati et al (2003) Global Burden of Disease and Risk Factors; Measuring the Global Burden of Disease and Risk Factors, Lancet, 362(9380):27180 .

Macmillan S, Peto R, Cutler J (1990). Blood pressure, stroke, and coronary heart disease, part 1. Prolonged differences in blood pressure: prospective observational studies corrected for the regression dilutional bias. Lancet. 335:765-774.

Mabuza MN, John VN, Jean-Pierre FL et al 2009.Reasons for non-compliance among patients with hypertension at Vanga Hospital, Bandundu Province, Democratic Republic of Congo: A qualitative study. African Journal of Primary Health Care \& Family Medicine. 1(1): 107-112

MacMahon, Peto, Cutler et al (1990) Collins, Sorlie, Neaton. Blood pressure, stroke, and coronary heart disease. Part Prolonged differences in blood pressure: prospective observational studies corrected for the regression dilution bias; Lancet. 335(8692): 765-74

Murray CJ, Lopez AD(1997). Global mortality, disability, and the contribution of risk factors Global Burden of Disease Study. Lancet.349 (9063):1436-42.

Onwubere BJ, Ejim EC, Okafor CI et al (2011). Pattern of blood pressure indices among the residents of a rural community in South East Nigeria Int J Hypertension. 6(2):104.

Onwuchekwa AC, Mezie-Okoye MM, Babatunde S (2012). Prevalence of hypertension in Kegbara-Dere, a rural community in the Niger Delta region, Nigeria. Ethn Dis. 22: $340-6$

Olatunbosun ST, Kaufman JS, Cooper RS et al (2000). Hypertension in a black population: Prevalence and biosocial determinants of high blood pressure in a group of urban Nigerians. JHum Hypertens. 14:249-57.
Ogah OS, Madukwe OO, Chukwuonye II, (2013) et al. Prevalence and determinants of hypertension in Abia state Nigeria: Results from the Abia state non-communicable diseases and cardiovascular risk factors survey. Ethn Dis.23:161-7.

Ogunniyi A, Baiyewu O, Gureje O. et al (2001). Morbidity pattern in a sample of elderly Nigerians resident in Idikan community, Ibadan. West Afr J Med. 20,227-31.

Padwal R, Strauss SF, McAlister FA(2001). Cardiovascular risk factors and their effects on the decision to treat hypertension. Evidence based review. BMJ.;322:977-980

Peltzer K, Phaswana-Mafuya N(2013), Hyperetension. associated factors in older adults in South Africa. Cardiovascular J Afr. 24:67-71.

Russell D, Wilson N(1991). Life in New Zealand Commission Report, Executive overview. Dunedin: University of Otago, 172-173.

Ulasi II, Ijeoma CK, Onwubere BJ, Ejikeme Arodiwe, Obinna Onadugo, Christian Okafor. High Prevalence of hypertension among market women in Enugu, Nigeria. Int J Hypertension, 2011, doi: 10.4061/ $\underline{2011 / 869675}$

Ulasi II, Ijoma CK, Onodugo OD(2010). A community-based study of hypertension and cardio-metabolic syndrome in semiurban and rural urban and BMC Health Serv Res. 10:71.

Vorster HH(2002). The emergence of cardiovascular disease during urbanisation of Africans. Public Health Nutrition 5(1:)239-43.

World Health Organisation (2002.); Reducing Risks, Promoting Healthy Life; The world health report, World Health Organization (1998); Life in the 21 st century: A vision for all; The World Health Report.

World Health Organization(2013). World Health Day Silent Killer, Global Public Health Crisis. WHO Campaigns;

Wyatt SB, Akylbekova EL, Wofford MR et al (2008). Prevalence, awareness, treatment, and control of hypertension in the Jackson Heart Study. Hypertension. 51, 65-656. 
Xia Li, et al (2013). Health Literacy in Rural Areas of China: Hypertension Knowledge Survey. Int. J. Environ. Res. Public Health, 10:1125-1138.

Yusuf S1, Reddy S, Ounpuu S et al (2001). Global burden of cardiovascular diseases: part I: general considerations, the epidemiologic transition, risk factors, and impact of urbanization. [PubMed indexed for urbanization. [PubMed indexed for MEDLINE]. 104 (22): 2746-53.

Zhao X, Li S, Ba S et al (2012). Prevalence Awareness, treatment and control of hypertensionamong herdsmen living at $4300 \mathrm{~m}$ in Tibet. Am J Hypertension. 25: $583-9$ 